\title{
THE ROLE OF EDUCATION IN TECHNOLOGY TRANSFER AND POVERTY REDUCTION IN NIGERIA
}

\author{
C.T. Jegede \\ Centre for Industrial Research and Development \\ Obafemi Awolowo University \\ Ile-Ife, Osun State, Nigeria
}

\begin{abstract}
The global issue of poverty remains one of the major challenges confronting the global village; even at the dawn of the 21st century with the millennium goal setting 2015 as the target year for poverty eradication. The variations in the extent of its severity across countries depend on many economic and social variables prominent among which is the educational structure, which often determine people's vulnerability to poverty. This paper therefore reports on the role of education in technology transfer and highlights strategic options for poverty reduction in Nigeria. The study made use of structured questionnaires. A total of one hundred and fifty-eight questionnaires were distributed to cover the whole population, out of which one hundred and fifty one (95.6\%) responded. This population was stratified into four, namely; Universities, Polytechnics, Colleges of Agriculture and Colleges of Education in Nigeria with a view to investigating the impact of government poverty alleviation programmes using educational development strategy. In spite of her abundant resources, poverty problem was acclaimed by the Respondents to exist in Nigeria. Despite the pessimistic stance of some earlier studies, respondents believed that appropriate strategies can be effective in reducing poverty in the country. They suggested the teaching of entrepreneurship education in Nigerian post secondary institutions and strengthening of sub contracting system to promote development of small and medium enterprises. The study concluded by attributing the persistence of economic poverty to low level of literacy, inappropriate economic structures and processes created by non-culturalisation of micro economic strategies such as sub-contracting system in the technological development framework of the state.
\end{abstract}

Keywords: subcontracting system, poverty reduction, technology transfer, entrepreneurship, literacy rate debugging strategy

\section{INTRODUCTION}

The world has witnessed unprecedented educational development in recent times through aca- demic research studies. Science education in particular continues to open up new research frontiers in information and industrial technologies. Never- 
theless, the problem of poverty remains one of the major challenges confronting the economically advanced and developing countries. In spite of diversity in the extent of severity and characteristics across nations, some countries including $\mathrm{Ni}$ geria, experience poverty amidst plenty (Mohan, 1996).

Many studies have been conducted to find lasting solutions to various dimensions of poverty reduction in Nigeria. For instance, White (1996), Mohan (1996), Ogunrinde (1998), Osiruemu (2003) and Srinivasan (2004) have all advocated for various poverty alleviation programs; yet, the problems of poverty persist. The failure of the programs is attributable to low literacy rate among the Nigerians and the yet-to-be harmonised educational and industrial structures of the informal sector with those in the formal sector. Monitoring the impact of poverty reduction policies (especially educational policies) of the Nigerian government requires research attention to make provisions for emerging needs; and the work reported here is an attempt in this direction. The study appraised poverty alleviation programs, the role of education in technology transfer and consequent poverty reduction.

Researchers including Chinwe and Ikpeze (2007), Ready (2004), Kakwani (2004) and Ravallian (2004) have all indicated that the level of economic development in this jet age is a reflection of the standard of living of the people which is manifested in the literacy rate, types of food, infrastructure and freedom enjoyed by the citi- zenry (Taylor, 1949; Bunting, 1979; National Development Plan II of Nigeria, 1970-1974). The assumption here is that the higher the literacy rate, the higher the standard of living (moving away from poverty line) of the people. Poverty line, according to Ehigiamosoe (2000) refers to the point on the poverty - prosperity continuum below which an individual is considered deprived. According to Srinivasan (2004), the poverty line, globally speaking is fixed at US\$1 (One dollar equals one hundred and twenty naira) per day. Although, this definition has attracted a lot of criticisms, in the absence of any appealing alternative, researchers continue to use it. It follows that the term 'poverty' refers to the economic condition of people whose income falls bellow US $\$ 1$ per day. In Nigeria, one hundred and twenty naira (US\$1) cannot guarantee a satisfactory daily meal of one citizen. Among the developing countries, Nigeria seems to be the worst hit by the poverty problem. Aguda (2007) remarked that India despite its huge population has least percentage of its citizens living below the poverty line (Table 1). Mauritius with the smallest labour force has the highest GDP per Capita (purchasing power parity) among the three countries.

The most noteworthy observation, in the recently concluded survey by the World Bank (White, 1996) on targeting communities for effective poverty alleviation in Nigeria, is the concentration of nearly 80 percent of all the 'poor' individuals in the two categories of communities that were classified as 'poor' and 'low income'. These two cate-

Table 1: Poverty Indicators and Comparative analysis of three Developing Countries

\begin{tabular}{llll}
\hline Indicators & Nigeria & Mauritius & India \\
\hline Population below poverty line & $60 \%($ year 2000) & $10 \%$ (year 2001) & 25\% (year 2002) \\
Labour force & 48.99 million & 585,000 & 509.3 million \\
GDP per Capita & US\$ 1, 400 & US\$ 13, 500 & US\$ 3, 700 \\
& (year 2006) & (year 2006) & (year 2006) \\
\hline
\end{tabular}

Source: Simeon Aguda, 2007 
gories of communities constitute only one-third of the total number of surveyed communities in the Niger Delta area of Nigeria. The average per capita income of the households in the 'poor' communities was reported to be 30 percent below the poverty line.

On the other hand, in the 20 percent of the communities that have been classified as 'non-poor,' all the households that were included in the survey had per capita expenditures well above the national median level. Indeed, the average income of all the households in this category of communities was more than five times greater than the average income per capita of the households in the category of 'poor' communities. The bottomline of this study is that in reality, poverty exists in Nigeria despite her abundant resources. The next discussion is on Japanese developmental strategy.

McCord (1973) in his work on the Japanese economy noted the contribution of sub-contracting and technology transfer to the growth of small industries in Japan. He also observed the contribution of ancillerisation system (sub contracting system) in India to the development of business link between the informal and formal sectors. McCord (ibid) defined sub-contracting as a process of sub letting contracts to smaller firms under the supervision of the contractor with the permission of the major contractor. In sub-contracting, the contractor is liable under the law for the inadequacy of the sub contractor. Sub-contracting system is a major component of 'The Japanese Model" and has been fundamental to the success story of technology transfer in Japan. The term technology transfer refers to ability to adopt, adapt, sustain and improve foreign technology (Olayide, 1976). Immediately after 1945, the Japanese economy was at low ebb and over eighty percent of the population lived below the poverty line. The economic and environmental conditions in Japan then were similar to those in Nigeria. After 1946, during the post $2^{\text {nd }}$ world war reconstruction era, the multinationals in the American economy, with the assistance of the Government opened up their home market for Japanese goods. Later the multinationals through the sub-contracting system monitored quality control system in Japanese factories. By this, Japanese products improved in quality; and with cheap labour in the 1970s, Japanese products began to compete favourably with American products. This situation created enabling environment for American multinationals to have subsidiaries in Japan. By 1990s, Japanese economy had developed technologically. The success story of Japanese economy was rooted in the educational system. In the 1960s, the university education in Japan was regarded as engine room to fight against poverty. Today, according to Nippon (2007), Japan, with a population of about 123.3 million people, literacy rate is put at ninetynine percent, average per capita income is US\$23, 270 per year and rate of employment is $1.9 \%$. The exchange rate is US\$1 $=153.0$ yen. The international reserve is about US\$80, 443 and annual growth rate of the economy is about $4.9 \%$. The value of stock rose $41.2 \%$ to 669 trillion yen in 1990 , the highest growth rate in history. Major religions include Shinto, Buddhism and Christianity. The climate varies from tropical conditions as in Nigeria to the temperate climate. Average annual rainfall is $1,460 \mathrm{~mm}$.

Jegede and Aguda (1998) in their search for reasons why Nigeria's rural areas stay undeveloped despite poverty alleviation policies of the government concluded that the rural areas would continue to remain poor because the urban areas continue to draw resources from the rural surrounding areas at an alarming rate thus rendering the rural areas poorer. This makes technology transfer almost impossible. According to Jegede and Aguda (1998), such phenomenon is in consonance with the saying of the Holy Bible in the book of Mathew chapter 25 verse 29 that "To those who use well what they are given, even more will be given, and they will have abundance. But from those who are unfaithful, even what little they have will be taken away.' Their findings made them to propose a theory called "the Mathew effect". 
Ogunrinde (1998) remarked that governments in developing countries introduce their development programme, including budget speeches with such "wishes" as: "the government wishes to improve the human conditions in this country," Yet, almost every strategy to bring this hope of poverty alleviation to reality has failed.

Corroborating Ogunrinde's (1998) work while investigating reasons for failures of poverty alleviation programme in African countries; Kakwani (2004) observed that the concentration of poor population in a relatively small number of communities is relevant for the design of costeffective public projects and poverty alleviation programmes. At present, the common methods of targeting projects and programmes in many developing countries including Nigeria (particularly the countries in which the necessary data for targeting individual households are not available) aim at reaching the entire population of a given sector, for instance, the rural sector, or the entire population in a particular region. According to Kakwani (2004), these methods of targeting are likely to be ineffective and are bound to require large resources. The implication of Kakwani's observation is that a programme targeting the entire rural population, for example, will include also all the non-poor rural households but leave out the urban poor. In other words, regional targeting is bound to include all the non-poor in that region but leave out all the poor that reside in the other regions. This means that many poverty alleviation programmes have probably failed because in an attempt to reach out to the poor, the rich have also been reached and benefited from the little resources thereby rendering the programme ineffective.

In his campaign speech, Agagu (2006) made reference to the policy of Ondo State Government of Nigeria as having used two criteria to measure the impact of the State Government Poverty Alleviation programme, namely education and accessibility to finance by the poor. Thus Agagu assessed the impact of the Ondo State Government
Poverty Alleviation policies using two criteria mentioned above and scored his administration between 2003 and 2007 high, with the provision at the local level of the following:

- Five (5) Technical Colleges

- Nineteen (19) Skill Acquisition Centers

- Eighteen (18) Business Training Centers

- Youth in Agriculture Farm and

- Micro Credit Agency

The implication of the above is that the Ondo State Government under the leadership of Governor Agagu officially recognizes the use of education and accessibility to micro finance as a measure of the impact of Government varying policies on Poverty Alleviation. The underlying assumption is that the more the number of educational institutions in a particular local environment, the higher the literacy rate and the more the impact of poverty alleviation programmes on the poor.

Igbokwe (2007) in its search for effective poverty eradication strategies in Nigeria advocated for a 'debugging' strategy. He defined 'debugging' as a problem solving technique commonly used in computer lexicon. It is a process of removing a bug from a program. A 'bug' is an error, mistake or defect in a program causing a malfunctioning. Bugs are detected through diagnostic checks and program tests and can then be eliminated by rewriting part of the program. According to Igbokwe (ibid), a bugged program presents a crisis situation. The diagnostic approach is expected to carefully examine the program to determine source of the bug, type, how to correct it and ways to prevent future occurrence. He concluded that when all these are done, the system begins to work properly. Likewise, Nigeria with a high level of poverty, listed among last ten impoverished nations, needs a lot of research studies carefully designed to monitor every poverty alleviation program of the government with a view of finding lasting solution to the poverty problem. According to him, about eighty million out of the Nigerian 
population (of about 103 million) lives below poverty line.

\section{EDUCATION, ITS DEVELOPMENT AND POVERTY ALLEVIATION IN NIGERIA}

Formal education was introduced into the country in the mid nineteenth century. It grew gradually till independence and thereafter assumed polymorphous dimensions. Education has now become one of the most important businesses of government and the society. This growth is partly as a result of the support that education received from the Nigerian government. This support is based on the direct relevance of sciences to technology transfer, development and utilisation needed in poverty alleviation (Ogunrinde, 1998). Here, technology transfer is defined by Bunting (1979) as ability to study existing systems, take advantage of the available resources and match it with foreign technology with the aim to develop new appropriate technology adapted to local needs.

The astronomical growth in higher institution and science education in Nigeria is indeed impressive if education is regarded as a social investment for the eradication of poverty. As part of the measures of the social returns rate to investment in education, there is the need to conduct studies to determine:

- To what extent has science education influenced the cultivation of science culture and attitude in the people?

- To what extent has education influenced policy making, technological transfer, national growth and development including alleviation of poverty, improvement in welfare and happiness of the masses and the citizenry?

- Has the rapid expansion in science education and curriculum within the Nigeria educational sector kept pace with the scientific knowledge system needed to solve her problems in the area of technology development?

- Has education at the secondary and tertiary levels prepared the grounds for technology transfer, technology adoption and utilization?

\section{RESEARCH METHODOLOGY \\ Sample Design}

The Study Population: Our study population consisted of 158 extension services centers and their top administrators out of which 151 (95.6\%) responded. The respondents were from 31 Universities, 31 Polytechnics, 55 Colleges of Education and 34 Colleges of Agriculture. They constituted the universe. The Administrators were chosen because they are the chief executives of the institutions with extension services, and as Nigerians they felt the impact of poverty alleviation programmes in their domains especially through the periodical evaluation forms collected from their field officers to determine the effectiveness and impact of their services on the community.

Sampling Frame (List of the Population): After identifying the population, the Researcher proceeded to list all units in the population, totaling 158 Extension Centres. The list of extension services centers, which was complied and maintained by the Federal Ministries of Agriculture, Education and Technology at Abuja was used for the purpose of selecting our sampling units.

Sample size and Sampling unit: For the purpose of effective coverage, the Researcher studied the whole population. Out of 158 questionnaires that were distributed, only 151 could be retrieved, representing 95.6 per cent of the sampling frame. The sampling units were the individual extension centres in our study population.

Sampling method/Population selection procedure: In order to have accurate data in the sample, the whole population was divided into four strata namely- Universities, Polytechnics, Colleges of Education and Colleges of Agriculture. With this kind of stratification, the accuracy of our data was improved. The research instrument was administered to all the extension centres.

Research Instrument: A self designed Poverty Alleviation Questionnaire (PAQ) was administered in order to investigate the impact of educa- 
tional extension services on poverty alleviation. Oral interviews were also conducted with some of the respondents and the CEO of the Federal Ministries of Agriculture, Education and Technology/ Science to extract more information to validate the data provided in the questionnaires.

Validation of Research Instrument and Testing: All information filled on the questionnaires was well scrutinized to ascertain its authenticity. A trial (pilot) test was conducted before the questionnaires were sent out to attest to the validity of the exercise.

EMPIRICAL ANALYSIS: LEVEL OF IMPACT OF GROWTH OF EDUCATIONAL INSTITUTIONS ON POVERTY ALLEVIATION IN NIGERIA

This section analyses the data collected for strategic options for effective poverty alleviation. Data were analysed in consonance with the stated objectives of the study for easy comprehension. The respondents were categorised using: sex, age, qualification, propensity to save and their potential purchasing power so as to know their composition. It is envisaged that their socio demographic and economic features will facilitate a better link with their expressed views. The study constructed a three point scale for evaluating the impact of educational institutions on poverty alleviation as follows:

Low (low level of impact)

Medium (level of impact at its infancy; not noticeable on the people)

High (high level of impact, Programmes successful)

The guiding research assumption here, all things being equal, is that the higher the number of institutions, the higher the literacy rate/level and the higher the propensity for technology transfer, and this is in consonance with earlier submissions made by Ogunrinde (1996) and Agagu (2006).

The result shows that the impact of education on poverty alleviation in Nigeria has been minimal (Table 2).

About $84 \%$ of the respondents were of the opinion that the growth in the number of educational institutions established in the country up to now has not helped much in alleviating poverty among the Nigerians. They explained that although the number of institutions has increased, so also the popu-

Table 2: Level of Impact of Growth of Educational Institutions on Poverty Alleviation as Perceived by Administrators ( $\mathrm{n}=151 ; 95.6 \%$ of $\mathrm{N})$

\begin{tabular}{|c|c|c|c|c|c|c|c|c|c|c|c|c|}
\hline \multirow{2}{*}{$\begin{array}{l}\text { Level of } \\
\text { impact }\end{array}$} & \multicolumn{2}{|c|}{1} & \multicolumn{2}{|r|}{2} & \multicolumn{2}{|c|}{3} & \multicolumn{2}{|c|}{4} & \multicolumn{2}{|c|}{5} & \multicolumn{2}{|c|}{6} \\
\hline & No & $\%$ & No & $\%$ & No & $\%$ & No & $\%$ & No & $\%$ & No & $\%$ \\
\hline LOW & 61 & 40.3 & 130 & 86 & 53 & 35 & 122 & 81 & 105 & 70 & 127 & 84 \\
\hline MEDIUM & 43 & 28.4 & 10 & 6.6 & 35 & 23 & 19 & 12.5 & 40 & 26.5 & 09 & 5.96 \\
\hline HIGH & 47 & 31.1 & 11 & 7.2 & 63 & 42 & 10 & 06.6 & 06 & 3.97 & 15 & 9.9 \\
\hline TOTAL & 151 & 100 & 151 & 100 & 151 & 100 & 151 & 100 & 151 & 100 & 151 & 100 \\
\hline
\end{tabular}

Source: Field Survey, 2007

KEYS

$1=$ to what extent has science influenced the cultivation of science culture and attitude in Nigerians

$2=$ to what extent has education influenced technological transfer in Nigeria

$3=$ to what extent has education influenced policy making in Nigeria

$4=$ to what extent has science education influenced technology utilisation in Nigeria

$5=$ to what extent has education influenced technological development in Nigeria

$6=$ to what extent has education influenced the national growth and alleviation of poverty in Nigeria. 
lation of the country has increased even at a faster rate thereby canceling the little impact which the education would have had on the poverty alleviation. The respondents further argued that many colleges are not utilizing all their potentials to realise the objectives of the colleges. For instance, many of the Federal Government owned utility schools have deteriorated to the extent that only about $48 \%$ of the students that enrolled for West African School Certificate Examination passed with five credits at one seating in 2006. This prompted the Federal Government to seek for an alternative strategy in managing the Unity schools by inviting the stakeholders to participate in the management of the schools while the Federal Government funds it.

When the respondents were asked to what extent has education influenced technological transfer in Nigeria; about $86 \%$ of the respondents agreed that the impact of education on technological transfer in Nigeria has been low. They felt that the literacy rate in Nigeria which was $49 \%$ in 1996 is now about $50 \%$. This is still low. The imposition of conditionalities by the International Monetary Fund (IMF) led to the 'drastic' fall in the value of the naira in the 1980s and subsequently the abysmal fall in the purchasing power, propensity to save and living standard (per capita income) of Nigerians. According to them, savings per family became very low and investment almost became impossible. For instance, the Nigerian Structural Adjustment Programme (SAP) which was introduced by the Babangida administration drastically lowered the value of the naira, created brain drain, made education expensive, and lowered literacy rates while simultaneously entrenching poverty especially among the low income people that constitute about $75 \%$ of the population. Consequently, the standard of living of many Nigerians suddenly fell and corruption emerged in the public sector.

The brain drain has negative effects on the Nigerian educational system. The university system was badly affected. Thus, there is apparent breakdown of the regular and critical discussions, pub- lications, reporting and monitoring which are essential to the health and discipline of any academic, research institutions and technology development. The loss in economic power of the people also led to loss of interest in legitimate jobs. Such loss of 'economic power' led to low purchasing power for the goods and services of the rural sector and hence the perpetuation of rural poverty.

Eighty-one percent of the respondents averred that the impact of science education on technology utilisation has been very low in Nigeria. They argued that the general nature of research reveals three levels of scientific research namely- basic, applied and adaptive. They suggested that the basic research should be undertaken by the traditional universities and some of the research institutes while specialized universities and the majority of the specialised research institutes should focus on applied research. Lastly adaptive research should be exclusively preserved for the agencies that deal with technology transfer such as the Centre of Industrial Research and Development of Obafemi Awolowo University and technology utilization centres like Cocoa Research Institute (CRIN) at Ibadan.

Science at the tertiary level is to contribute to science data base on technology development. A review of the laws establishing some Nigerian Universities show that no specific mandates either in applied or adaptive modes were given to specific universities to undertake research for particular purpose, neither is any of them so specifically equipped. This assertion is supported when one examines some of the edicts establishing the universities. The University of Ife Provisional Council Law of $8^{\text {th }}$ June, 1961, with the University of Ife Edict of $11^{\text {th }}$ June 1970, is a typical example. The Federal Government Decree No 23 of 1975 which led to the take-over of the existing universities (Ife, Lagos, Nsukka, Benin and Zaria) did not improve the situation either. The universities established after this period followed same pattern. Likewise the universities of technology established between 1980 and 1983 had similar mandates as contained in the Federal Universities of 
Technology Act of June 1993. Although the universities of Agriculture Decree No. 48 of November 2, 1992 had specific mandates for research in agriculture, the type of agricultural research that the universities engaged in and have since their inception was not different from those traditional universities like that of Agricultural Engineering and Extension of Obafemi Awolowo University, Ife. Ogunrinde (1998) had earlier observed these shortcomings on the part of Nigerian universities.

The general poor funding of the universities by the Federal Government is also being contended. The Nigeria Universities Commission (NUC) has at different times, supported the establishment of private universities in Nigeria as the Federal Government can no longer cope with the funding of universities. The availability of funds, infrastructures and facilities (for basic and applied research) in tertiary institutions, is far short of expectation. The need for better co-ordination between the universities and the research institutes can not be emphasized enough. The respondents further revealed that the Longe Commission Reports on Higher Education (1991) recommended that both scientific and technological research and development activities be undertaken by the Research Council. The respondents opined that the Research Council needs to improve on her capacity building so as to perform better in her planning and implementation of research activities towards technology development in Nigeria. As at now, the respondents confirmed that the economy has not felt its impact much as expected.

When some respondents were asked to what extent science had influenced the cultivation of a scientific culture and attitude in Nigerians; $40.3 \%$ of the respondents claimed the impact has been low, while $28.4 \%$ felt the impact was average and another $31.1 \%$ claimed the impact was much. The respondents opined that the advances in sciences research are dependent on technological advances while such findings are used in further development in technology through technological transfer; using small and medium industries including agriculture. They acclaimed that most universities in Nigeria lack relevant up-to-date equipments and facilities for research and where any of such exits, it is not maintained or at best poorly maintained. Poor funding of the universities has made it impossible for them to contribute meaningfully to basic and fundamental researches which need modern facilities.

Besides, the Nigeria social environment in which scientists work makes it 'hard' for them to concentrate on such research as poor social services create a lot of disincentives. Such distractions include: poor work reward system, high cost of living which forces researchers to look for sources of complementary income; erratic electricity supply, high cost of transportation, unstable fuel supply, all which cause delay in research. The situation has led to brain drain. Ogunrinde (1995; 1998) and Ekong (1998) have earlier observed these factors in their studies.

The summary of key findings is that:

- majority of the respondents did not agree that science education has influenced the cultivation of scientific culture and attitude among the people of Nigeria; and thus has not contributed much to poverty alleviation.

- majority of the respondents did not agree that education has influenced the technological transfer in Nigeria; similarly, education has not alleviated poverty much in the country.

- some respondents (about 42\%) agreed that education has influenced policy making in Nigeria;

- majority of the respondents did not agree that science education has influenced technology utilization among the people of Nigeria; likewise it has not contributed much towards eradication of poverty in Nigeria.

- majority of the respondents did not agree that science education has influenced technological development in Nigeria; and therefore, poverty still exist and lastly, 
- majority of the respondents did not agree that education has influenced national growth and alleviation of poverty in Nigeria

\section{POVERTY ALLEVIATION: STRATEGIC OPTIONS}

The respondents were of the opinion that nonculturalisation of micro economic policy with particular reference to educational and subcontracting strategies of the state is the major reason for the perpetuation of poverty in Nigeria. Thus, they suggested Nigeria will need to turn to the educational sector, with emphasis on adult literacy and entrepreneurship development programme both at work place and the post secondary institutions. They opined that the Universities and the Polytechnics need to put more emphasis on equipping the students with entrepreneurial skills to enhance the future of Nigerian small and medium industries including small scale farmers. The respondents averred that these small firms must be tied to large scale industrial firms through well supervised sub-contracting system. The respondents added that in doing this, the Nigerian legal system needs to be overhauled to protect the laws guiding sub contracting system. Also the three tiers of Government especially the local government must be genuinely concerned to assist the small firms to meet up to the expectations of the large industries especially in the areas of quality control. Generally speaking, industrial occupations require four major factors of production and they are: land, labour, capital and the entrepreneurial skills. The employability and use of any of these factors in production has historical, social and political antecedents with relevant implications for development or underdevelopment. The respondents believed that if well harnessed, factors of production would assist to alleviate poverty within the industrial/agricultural sector.

\section{CONCLUSION AND RECOMMENDATIONS}

We defined the central problem of this study in terms of effect of educational growth on allevia- tion of poverty in Nigeria. Many scholars believe that the higher the literacy level, the higher the standard of living of the people, thereby alleviating poverty. However, these studies failed to properly link literacy with poverty alleviation through effective subcontracting system as now being suggested. This study has awakened our consciousness in this direction. Nevertheless, there is the need for more studies that will further link literacy with poverty alleviation programmes through effective sub-contracting system. In Nigeria, many research studies have been carried out on poverty alleviation but none, to the best of our knowledge has looked at sub contracting system as a tool that can be used to alleviate poverty. This situation left a critical gap to be filled in transfer of technology literature. The absence of Nigerian based research data on sensitive subject as this; in the transfer of technology was considered unsatisfactory. Especially for the growth of knowledge in an area, where there is an acknowledged empirically based body of knowledge (e.g. in Japan) that can be used to clamor for strong support for the introduction of well guided sub contracting system to support small firms.

In view of this, the following recommendations are made:

To alleviate poverty, it is necessary to assist the poor in the rural and urban areas to raise their level of economic and literacy attainment. Today, extension works aim principally at assisting small and medium enterprises including rural farmers to raise their standard of living but without any feasible effort to culturise or sustain such intervening assistance. Extension programmes should not only target people but cautious effort should be made to link them with the formal private sector through entrepreneurship training programs and subcontracting system by providing appropriate legal framework, business incubators and industrial estates at national, state and local levels.

Finally, mass literacy programmes in Subcontracting and Entrepreneurship should be organized for the small and medium industrialists and 
farmers. The training costs should be subsidised by Local, State and Federal Government. On this, the Department of Industry, under Local Government should be established to oversee this function.

\section{REFERENCES}

Agagu, O (2006). 'Reject Poverty Today' an address presented at the inception of the governorship race for the Ondo State governorship seat. Akure: Ondo State Government Printing Press

Aguda, Simeon (2007). 'The Fundamentals' in Aguda S. (ed.) The Financial Standard: A Nigerian weekly financial publication, July 23 Lagos: FS publication

Bunting, A.H (1979). 'Science and technology for human needs, rural development and the relief of poverty' International Agricultural Development Service (IADS) Occasional paper; adapted from the paper presented at the OECD Workshop on scientific and technological cooperation with developing countries Paris: April 11, 1978.

Chinwe, H and Ikpeze, B (2007). 'Web-based inquiry learning: Facilitating thoughtful literacy with Web Quests' in Judith Mitchell and Ray Reutzel (eds.) The Reading Teacher A Journal of International Reading Association 60(7) April.

Ehigiamosoe, G. (2000). Poverty and Microfinance in Nigeria Benin City: Ob-zed Publishers

Ekong, E. E. (1988). An Introduction to Rural Sociology Ibadan, Nigeria: Jumak Publishers Ltd.

Fabiyi, Y.L. (1985). "Land Policy in the Development of Agriculture: The Response of Farmers in Ondo and Oyo State to Land Use Act" Ife Journal of Agriculture. 7 (1 \& 2): 80 -94 .

Gilbert, P.G and Lovegrove, H.N. (eds) (1972). 'Science in Africa'. A report of the Sixth
Lanerholme Inter-University Conference in Africa London: Heinemann.

Hayami, Y. and Ruttan, V.M. (1984). "Towards a Theory of Induced Institutional Innovations" The Journal of Development Studies 20 (4), July

Igbokwe, J. (2007). 'Effective Poverty Eradication Strategy' The Punch; A daily newspaper in Nigeria, Thursday, July 19, 2007 p 14

Jegede, C. T. and Aguda, A. S. (1998). 'Why Nigeria's Rural Areas stay underdeveloped: Theoretical and Empirical Considerations'. The Quarterly Journal of Administration, Vol. XXVI Nos. 3 \& 4, April/July, Obafemi Awolowo University, Ile-Ife

Kakwani, N. (2004). "New Global Poverty Counts" in World Bank Group Findings: African Region. Washington D.C.: Knowledge Networks, Information and Technology Center. No. 68, August 1996. pp. 9-12

McCord, W. (1973). "The Japanese Model" in Wilber, Charles K. (ed.) The Political Economy of Development and Underdevelopment. New York: Random House.

Mohan, P.C. (1996). "Nigeria: Poverty in the midst of plenty- The Challenge of Growth with inclusion" in World Bank Group Findings: African Region. Washington D.C.: Knowledge Networks, Information and Technology Center. No. 68, August 1996.

National Commission of Colleges of Education (2005). The Nigeria Teacher Today National commission of Colleges of Education, Kaduna, Vol. 5 pp $2-4$

Nehru, J.L. (1969). 'The Discovery of India' in Kumar, R. (1983) Science and Technology: The Indian Experience Rivers State University of Science and Technology Public lectures 1983-1984. pp. 3-15.

Nigeria, Federal Republic of (1991). 'Higher Education in Nineties and Beyond' Report of the Longe Commission Review of Higher Education in Nigeria, (Main Report) pp 193 
Nippon (2007). Jetro: Business Facts and Figures. Tokyo, Japan: Japan External Trade Organisation (JETRO)

Ogunrinde, S.I. (1985). "The Impact of the Agricultural Inputs and Services Units (AISU) in Oyo State" Ife Journal of Agriculture 7 (1 \& 2): $95-110$.

Ogunrinde, S.1. (1995). “Agricultural Technological Development in Nigeria: A Sociological Review of the Yorubas". Ibom Journal of Social Issues University of Uyo, 1 (2): 148161.

Ogunrinde, S.I. (1996a). "Trends and Developments in Extension Science: Implications for Agricultural Transformation in Nigeria" In Modo, I. O et al (eds.) Hi-Points in Social Sciences (In Press).

Ogunrinde, S.I. (1996b). 'Rural Development and Agricultural Information Management System in Nigeria' Paper presented at the $3^{\text {rd }}$ international conference on science and technology in Reconstruction and Development, University of Natal, South Africa, September 23-26.

Ogunrinde, S.I. (1997a). "Managing Agriculture Extension for Rural Development in Nigeria". A paper presented at the Third National Annual Conference of the Agricultural Extension Society of Nigeria (AESON) held at Obafemi Awolowo University, Ile-Ife. March 6-9.

Ogunrinde, S.I. (1997b). “Agricultural Education and Technology Needs for the Development of the Agricultural Sector of Nigeria" Paper presented under Special Topic Series of the curriculum and Audio-vision instruction (OAI) Department of ACE, Ondo State of Nigeria

Ogunrinde, S.I. (1998). "Perception of Agricultural Science in Secondary Schools: A Survey of Students in Ondo State of Nigeria." The Nigerian Teacher Today. National Commission for Colleges of Education, Kaduna, Vol. 5
Olayide, S.O. (1976). Economy Survey of Nigeria 1960-1975. Ibadan: Aromolaran Publishing company Ltd

Osiruemu, E. (2003). "The Feminisation of Poverty and it's Alleviation in Nigeria: An Appraisal of some Government Programme; Abraka: Delta State University, Abraka $\mathrm{Hu}$ manities Review Journal 3(2): 58-72

Parsons, T. (1954). The Social System Glencoe, Illinois: The Free Press.

Ravalian, M. (2004). "Monitoring Progress Against Global Poverty" in World Bank Group Findings: African Region. Washington D.C.: Knowledge Networks, Information and Technology Center. No. 68, August 1996. pp. $12-15$

Ready, S. (2004). "A Capability based approach to Estimating Global Poverty" in World Bank Group Findings: African Region. Washington D.C.: Knowledge Networks, Information and Technology Center. No. 68, August 1996. pp. 6-8

Roling, N. (1987). Extension Science: Information systems in Agricultural Development Cambridge: Cambridge University Press.

Srinivasan, T.N. (2004). “The Unsatisfactory State of Global Poverty Estimation." In Alenjedro Grinspun (ed.) International Poverty in Focus Geneva: UNDP, September 2004. pp 3-4

Taiwo, C.O. (1975). "Science Curriculum Development in Nigeria". The text of a paper presented at Science Teachers Association of Nigeria (STAN) National Conference at the U.N.N. Calabar Campus, Aug. 25-29.

Taylor, F. S. (1949). Science: past and Present. London: William Heinemann

White, P. (1996). "Nigeria: Targeting Communities for effective poverty alleviation" in World Bank Group Findings: African Region. Washington D.C.: Knowledge Networks, Information and Technology Center. No. 68, August 1996. 